\title{
Universities and Science Parks: Engagements and Interactions in Developing and Attracting Talent
}

Eduardo Cadorin, Eloïse Germain-Alamartine, Dzamila Bienkowska and Magnus Klofsten

\section{Book Chapter}

Cite this chapter as:

Cadorin, E., Germain-Alamartine, E., Bienkowska, D., Klofsten, M. Universities and Science Parks: Engagements and Interactions in Developing and Attracting Talent, In Thorsten Kliewe, Tobias Kesting, Carolin Plewa, Thomas Baaken T. (eds), Developing Engaged and Entrepreneurial Universities: Theories, Concepts and Empirical Findings, Singapore: Springer; 2019, pp. 151-169.

ISBN: 9789811381294 (print); 9789811381300 (print)

DOI: https:// doi.org/ 10.1007/978-981-13-8130-0_8

Copyright: Springer

The self-archived postprint version of this journal article is available at Linköping University Institutional Repository (DiVA):

http:// urn.kb.se/resolve?urn=urn:nbn:se:liu:diva-160680 


\title{
UNIVERSITIES AND SCIENCE PARKS: ENGAGEMENTS AND INTERACTIONS IN DEVELOPING AND ATTRACTING TALENT
}

\author{
Eduardo Cadorin ${ }^{1}$, Eloïse Germain-Alamartine, Dzamila Bienkowska and Magnus Klofsten
}

Abstract Throughout the history of Science Parks, many studies have shown that they have ceased to be mere facilitators of physical spaces to become important providers of services and resources to their tenants. Universities situated in or next to them play a key role in getting engaged in the development and the attraction of talent to Science Parks, to their tenant firms as well as to the region. Considering that skilled professionals are one of the resources that companies seek the most, Science Parks have dedicated numerous activities and means to become even more attractive to talented individuals, which can especially be found in entrepreneurial universities. In this study, we review the literature regarding the interactions existing between Science Parks or their tenants and their local universities. Talent recruitment and entrepreneurship issues are addressed as the building blocks of these interactions. We strive to identify types of interactions that could differ in function of the maturity levels of the firms since their aims are not the same: at an early stage, firms tend to focus more on growth, whereas at a later stage, they tend to focus more on their development. We then point out policy implications, concerning both entrepreneurial or engaged universities and Science Parks.

\section{INTRODUCTION}

Universities' ability to generate both knowledge and empowered individuals positively influences regional outcomes (Florida, 1999; Gibb \& Hannon, 2006). In this sense, Charles (2006) highlights the important role of universities 'in the for-

\footnotetext{
${ }^{1}$ Eduardo Cadorin (困), Eloïse Germain-Alamartine, Dzamila Bienkowska and Magnus Klofsten

Linköping University, Helix Competence Centre, Division of Project, Innovation \& Entrepreneurship, Department of Management and Engineering, 58183 Linköping, Sweden.

E-mail: eduardo.cadorin@liu.se
}

Cite as: Cadorin E., Germain-Alamartine E., Bienkowska D., Klofsten M. (2019) Universities and Science Parks: Engagements and interactions in developing and attracting talent. In: Kliewe T., Kesting T., Plewa C., Baaken T. (eds) Developing engaged and entrepreneurial universities. Springer, Singapore (151-169). Springer, Singapore. 
mation of human capital through the education of students as well as training activities for people already in work' (ibid p.119). Universities thus need to evolve along with their economic environments over time to not only survive but also better meet the need of these environments. Etzkowitz (2003) states that the assignment of the university has been evolving, assuming a new role in economic and social development. Back in the 17th century, in their first years of existence, even star universities, such as Harvard, did not have a real economic impact, as the economy was based on the combination of physical labour and financial capital only (Audretsch, 2014). Later, in the 19th century, the emergence of applied sciences seems to shift the role of universities: knowledge began to play a major role in the economy (Youtie \& Shapira, 2008). During the world wars, research results proved to be useful for the American army in particular (Audretsch, 2014). From then on, some universities have become 'entrepreneurial' (Uyarra, 2010, p. 1230). The research university seems to have been transformed to encompass the concept of entrepreneurship, changing into 'a teaching, research and economic development enterprise' (Etzkowitz, 2003, p. 110). Processes of the entrepreneurial university lead to the creation of firms to bring research results into the market, to the transfer of technology, but also to the improvement of university's internal processes and structure (Kesting, Kliewe, \& Baaken, 2014) - in short, to the use of spill-over mechanisms in order to diffuse their knowledge to their economic environment (Audretsch, 2014).

In this context of evolving economic environments, Science Parks work as facilitators stimulating and supporting the growth of companies of all maturity levels (Rothaermel, Agung, \& Jiang, 2007). Today's Science Parks are the result of transformations and evolutions of the first parks that began to operate in the second half of the $20^{\text {th }}$ century in the United States (Colombo \& Delmastro, 2002; National Research Council, 2009). US policy initiatives, such as the Bayh-Dole Act and the National Cooperative Research Act in the late 1970s and early 1980s, allowed universities and companies to form partnerships to market the results of university research (Link \& Scott, 2006). New US Parks have emerged in this scenario of university-industry collaboration and have become a model for other countries to develop their Science Parks (Westhead, 1997). Regional development was the first driving force for the creation of Science Parks, fostering the revitalisation of local industries, mainly through the transfer of knowledge and technology from the university (Vásquez-Urriago, Barge-Gil, \& Rico, 2016).

The partnership with the university is relevant to Science Parks due to its ability to produce and distribute human capital (Mellander \& Florida, 2011), and to the influx of students (Etzkowitz \& Klofsten, 2005) and researchers with advanced ideas and skills (Cadorin, Johansson, \& Klofsten, 2017). Considering the university as a 'provider of talent' (Florida, 1999, p. 68), graduate students, alumni, researchers, and professors are all examples of talent in this study. Their knowledge and skills are the driving forces behind the growth of park companies as well as the development of new business in a Park. In this partnership, universities can be considered entrepreneurial, since the commercialisation of research is part of the regional economic development, and/or engaged, to the extent that they seem to 
get involved in the social development of their regions, for instance, through a role of 'workforce development' (Breznitz \& Feldman, 2012, p. 145). Moreover, because qualified people are a sought-after resource, Science Parks carry out different activities on their own or in collaboration with stakeholders to recruit talent typically found in higher education institutions, such as universities.

University-industry interactions have been discussed extensively over the past few decades. Perkmann et al. (2013), for instance, review the literature on universityindustry relations. They study 36 scientific articles published between 1989 and 2011 that deal mostly with knowledge transfer through the application of research. A focus is made on 'academic engagement' that occurs both in formal and informal ways (Perkmann et al., 2013, p. 1). However, in this large panel of references, Science Parks are mentioned only three times (Clarysse, Wright, Lockett, Van de Velde, \& Vohora, 2005; Phan, Siegel, \& Wright, 2005; Van Dierdonck, Debackere, \& Engelen, 1990), and neither talent nor recruitment is ever introduced, as the teaching role of universities does not seem to be the focus of the literature review. Academic publications dealing with university - Science Park interactions for talent recruitment have been reviewed in this chapter. Research often seems to deal with both the issues of talent recruitment and of university Science Park interactions separately (Florida, 1999; Zhu \& Tann, 2005). It also seems to address talent attraction to the Science Park rather implicitly (Radosevic $\&$ Myrzakhmet, 2009; Schiavone, Meles, Verdoliva, \& Del Giudice, 2014). The objective of this study is to study both issues of talent recruitment and university Science Park interactions in an explicit manner.

This study contributes to the research on entrepreneurial and engaged universities by addressing the role of universities in the economic and social development of their regions. It aims to identify the types of interactions and engagements occurring between Science Parks and their nearby universities, understanding and qualifying the university's role in developing and attracting talent that firms in Science Parks can recruit later on. In addition, this study also recognises and points out policy implications, concerning both entrepreneurial and engaged universities and Science Parks.

In particular, the following research questions are addressed: (i) What kinds of university - Science Park interactions aiming at recruiting and developing talent are discussed in the literature? (ii) How do the formal and informal interactions between universities and Science Parks contribute to the recruitment and development of talent for park firms related to their maturity levels?

\section{METHOD AND DATA}

The literature review aims to identify different types of interactions between universities and Science Parks regarding talent development and attraction to a Sci- 
ence Park, thus addressing our first research question. The analysis of the interactions found in the literature leads to the development of a theoretical model that suggests an answer to our second research question. Finally, some cases are highlighted that aim to illustrate how university - Science Park interactions may enable the recruitment of talent into the Science Park.

We searched the databases Google Scholar, Scopus, and Web of Science by using a list of keywords (Table 1), as well as queries associating some of these different keywords to specify our requests. In addition, we used references' lists of the selected papers to widen our collection of readings. We thus proceeded to an iterative process that comprised the following steps: (i) the collection of a set of articles; (ii) the adjustment of the collection with the rejection of some studies; (iii) the completion of the sample with the use of sources cited in the selected articles; (iv) a new adjustment of the sample with the rejection of some studies; (v) until the stage where the whole set of relevant cited sources in our sample had been explored. The search for new sources ended when the new references obtained by our interactive search process were either already in our set of articles or did not really contribute to the research. We initially determined that a minimum of 30 articles would be required, mainly covering the last 20 years of publication on the subject. A study was rejected from our collection if that study was not explicitly discussing - in the theory or through an example - at least one relationship that was (i) occurring between a university and a Science, Technology or Research Park; or (ii) dealing with human capital. This literature review is thus the result of the collection and the study of a final sample of 37 academic papers that explicitly discuss relationships between universities and Science Parks regarding the development or attraction of talent.

Table 1. List of keywords used to search databases.

Attract

Cooperation

Entrepreneur

Innovation

Recruit

Retain

Skill

Technology park

\section{Collaboration}

Engagement

Incubator

Interaction

Research park

Science Park

Talent

Technopark

University 
We chose to study some interactions occurring between Linköping University (LiU) and Science Park Mjärdevi (SPM) to illustrate our findings from our study of the literature. Three main reasons motivate the choice of these descriptive cases: (a) their relevance, since LiU has been characterised as 'entrepreneurial' (Svensson, Klofsten, \& Etzkowitz, 2012, p. 1) and the relationship between LiU and SPM focusses not only on the commercialisation of university knowledge but also on the recruitment and development of talent (Cadorin, Johansson, \& Klofsten, 2017); (b) the accessibility and the amount of data available, since SPM has had a close relationship with LiU for more than 30 years (Etzkowitz \& Klofsten, 2005); and both LiU and SPM share geographical, social and cognitive forms of proximity (Boschma, 2005); (c) the possibility to illustrate a broad spectrum of activities and connections that can contribute to the engaged university.

In order to build the cases, we first conducted an in-depth study on the websites of both institutions to identify interactions that would potentially result in talent recruitment. Once we had identified the areas involved on both sides, we scheduled meetings or sent questionnaires via email to the persons in charge of these areas. Semi-structured interviews were conducted with two representatives from Science Park Mjärdevi: the former CEO that was involved since the creation of the Science Park and had managed it for 30 years; and the current manager of community and employer branding. In addition, we met one of LiU Innovation Office's advisors, as well as one senior advisor of Demola. A follow-up interview was held with the SPM's Community and Employer Branding Manager to supplement the information collected during the first meeting, but also to obtain information about a new activity, and to test our theoretical model. In total, three questionnaires were sent by electronic mail, and four face-to-face interviews were conducted, that lasted between 30 minutes and 1 hour each. In the end, we presented the written cases to each respondent to validate the information, and we brought the necessary adjustments according to the feedback received from them.

\section{UNIVERSITY - SCIENCE PARK INTERACTIONS TO RECRUIT TALENT: A REVIEW OF THE LITERATURE}

In the literature, Science Parks are described in different ways, for example, research parks, technology parks or science and technology parks (Hommen, Doloreux, \& Larsson, 2006). The inconsistency in definitions can express political or financial issues, which emphasise certain individual characteristics of each park. In the end, this lack of uniformity makes it difficult to apply the term consistently and broadly. Definitions from international associations, such as IASP (IASP, 2017) and UKSPA (UKSPA, 2017), point out that parks should stimulate and provide the required support for university-generated knowledge to flow appropriately to park companies in addition to offering high-quality business services and a prestigious location. Colombo and Delmastro (2002) and Westhead (1997) state that the establishment of connections with universities is an essential 
pillar for Science Parks to achieve their objectives. Moreover, Science Parks mainly aim to nurture the relationship between universities and industry (Minguillo, Tijssen, \& Thelwall, 2015), promoting proximity among them in several ways, such as in geographical, technological, and organisational ways (Vásquez-Urriago, Barge-Gil, \& Rico, 2016). The result is an environment that fosters innovation.

According to Audretsch, universities' roles are evolving to become 'broader and more fundamental - to provide thinking, leadership and activity to enhance entrepreneurship capital' (Audretsch, 2014, p. 320), driven in large part by external expectations (Pavlin, Kesting, \& Baaken, 2016). In addition to research applications, a new focus is indeed made on 'creating entrepreneurial thinking, actions, institutions', collectively 'entrepreneurship capital' (Audretsch, 2014, p. 319). This focus seems to be in line with the new 'engaged' mission of universities (Uyarra, 2010, p. 1230), where knowledge sharing is dependent on social capital and relational involvement (Charles, 2006; Clauss \& Kesting, 2017). Uyarra indeed defines engaged universities as 'enablers of regional development', that provide 'adaptive responses' to 'regional needs' through a 'contribution of higher education to social, cultural and environmental development' (Uyarra, 2010, p. 1238). Gibb et al. (2013, p. 1) also state that the 'societal engagement' of universities is a way for them to behave entrepreneurially.

The recruitment of graduates from the university to Science Parks is frequently mentioned in the literature (Hommen, Doloreux, \& Larsson, 2006; Löfsten \& Lindelöf, 2002; Vedovello, 1997; Walcott, 2002) and confirms the definition of the university as a 'provider of talent' by Florida $(1999$, p. 68). The recruitment of graduates of a nearby university can thus be considered as talent recruitment. It, of course, can be made without the help of a university, once the training of the graduate is completed: the process can happen with exchanges occurring only between the graduate and the hiring company. However, the recruitment can also be a real interactive process between the Science Park, through the implementation of internship programmes, for instance (Hommen et al., 2006; Huffman \& Quigley, 2002; Walcott, 2002). This process enables the company to spot talent that could be worth recruiting later on to develop the company and also enables the student to build skills during an internship by acquiring know-how. This practice is more and more frequent, all the more as some universities now demand a certain amount of time spent working for an organisation as a requirement for graduation. Another way for companies to detect talent is to get students involved in their projects (Vedovello, 1997). In the framework of a course, for instance, the application of theory is made through a semester project that is physically conducted at least partially within the university by students, with professors as advisors, but for a client, that is the company that brought the project. Some tenant firms having spotted talent even proceed to grant scholarships in exchange for signing a contract of employment after graduation (Huffman \& Quigley, 2002).

Direct recruitment, job fairs to present the company on campus and conducting interviews are also often used to attract talent (Hommen et al., 2006; Huffman \& 
Quigley, 2002), as well as headhunting (Zhu \& Tann, 2005). Headhunting can be practised by several actors: the hiring firm in the Science Park, the Science Park management office, or a headhunting company, that could also potentially be a member of the Science Park. The formality of these interactions is justified by the signature of a written contract: internship agreements in the case of internships, signed by the student, the firm and the university; an agreement between the firm and the university to define the boundaries of the partnership and of the project for which students work for free in the framework of their training; an agreement for the job fair, in order to fix eventual fees and to clarify the support provided by the university (such as space or material); and headhunting can also imply an agreement between the headhunting organisation and the university or a part of the university (such as an alumni organisation) to exchange contacts or to publish advertisements. Firms having a higher level of maturity do these interactions with universities looking for talent to renew their business know-how (Klofsten \& Jones-Evans, 1996).

However, there are also interactions mentioned in the literature that deal with onpark firms with a lower level of business maturity, most of them being new companies emerging from universities or other park firms. Overall, Science Parks enable a conducive environment for innovation (Cadorin, Johansson, \& Klofsten, 2017), engaging in different activities, such as organising events to create an arena where researchers can encounter innovators and entrepreneurs. In this sense, Science Parks bring industry and universities closer together, inspiring them to participate in regional economic development; they are one example of regional innovation systems (Coenen, 2007). In such systems, universities spread their knowledge through education and training programmes (Klofsten \& Jones-Evans, 2013;

Vedovello, 1997). These programmes target students, providing them resources to become self-employed (Huffman \& Quigley, 2002), but they also focus on entrepreneurs from Science Parks, in the form of formal courses or more original forms, such as breakfast seminars (Klofsten \& Jones-Evans, 2013). But universities can go beyond their role of qualifying individuals through the commercialisation of their research results (Cai \& Liu, 2015; Coenen, 2007), and they can behave entrepreneurially by relying on their incubators to support entrepreneurial students (Huffman \& Quigley, 2002), providing facilities (Walcott, 2002;

Westhead \& Storey, 1995) and services needed to operationalise their new firms (Cadorin et al., 2017). This kind of interaction represents a formal link between universities and Science Parks.

The lack of financial resources is a common problem in the initial stages of a firm that entrepreneurs need to overcome. To help them through this challenging period, universities and Science Parks work together by promoting competitions where students present their business plans to a panel of judges and the winners receive funding from participating companies (Huffman \& Quigley, 2002).

The geographic proximity is the most perceived way of Science Parks and universities interacting for talent recruitment. It is informal to the extent that the university is seen as a prestigious scientific institution, thus conferring a positive image 
to companies of all levels of maturity that choose to be located in its surroundings (Felsenstein, 1994; Mellander \& Florida, 2011; Quintas, Wield, \& Massey, 1992; Tan, 2006; Vásquez-Urriago et al., 2016). The physical proximity within a cluster triggers the existence of informal information networks (Tan, 2006), that, strengthened by personal contact (Cadorin et al., 2017) through an alumni network, for instance (Huffman \& Quigley, 2002), can enable the flow of information concerning the need for or the availability of talent, but also the mobility of human resources for the creation of new firms (Dahlstrand, 1997) or for the transmission of knowledge and skills (Tan, 2006; Zhu \& Tann, 2005). Companies can also convey the needs of technology users and can guide university research according to market demands through these informal networks of information (Martínez-Cañas \& Ruiz-Palomino, 2010). Moreover, as universities internally support the entrepreneurship spirit of its students and researchers (Bienkowska, Klofsten, \& Rasmussen, 2016; Díez-Vial \& Montoro-Sánchez, 2016; Etzkowitz \& Klofsten, 2005; Klofsten \& Jones-Evans, 2013; Klofsten \& Lundmark, 2016; MartínezCañas \& Ruiz-Palomino, 2010), the physical proximity enables entrepreneurs from universities to use the facilities of Science Parks informally (Cadorin et al., 2017).

Talented individuals are known to be attracted to 'progressive environments' (Florida, 1999, p. 71), with a high quality of life, infrastructures, employers, and other talent, which is what Science Parks seem to embody. In general, Science Parks do not need formal contracts with the university to create such environments, even though the involvement of the university in the park ownership or management certainly implies one, making it a formal interaction (Albahari, Catalano, \& Landoni, 2013). However, the image of the Science Park and its brand (Cadorin et al., 2017) are crucial to attracting talent, and the informal interaction between the Science Park and the university lies in their mutual enhancement of image, through individual initiatives - for instance, academic publication of quality for the university - but also joined initiatives, such as research partnerships or co-organisation of events. Moreover, the interactions can be made directly by the Science Park management office (Löfsten \& Lindelöf, 2002; MartínezCañas \& Ruiz-Palomino, 2010; Phillimore, 1999; Vedovello, 1997), without implying the writing and signature of agreements each time.

The use of the Internet (social media, newsletters) by the Science Park, its tenant companies (Cadorin et al., 2017), the university, but also by mixed organisations owned by both the university and the Science Park are also informal interactions to be noted; they are useful in sharing needs for skills and particular profiles as well as events, successes, and a positive image of the environment; in other terms, to attract talent to the Science Park. Thus, the importance of social networks should not be underestimated; not only the virtual but also real ones, such as alumni networks (Huffman \& Quigley, 2002; Walcott, 2002) that are precious resources to search for talent for the Science Park and the region, especially from their nearby university. Apart from alumni, the staff of the university can also use its network to observe the labour market of the Science Park. A case is described by Huffman and Quigley (2002, p. 407): 'a staff member of Berkeley's Haas 
School of Business Recruiting Office spends one day a week in Silicon Valley, marketing the business school directly to selected firms and collecting information on Silicon Valley hiring trends'.

Informal interactions between universities and Science Parks seem to occur more spontaneously and more easily to implement to the extent that formal agreements are costly (in time, money and human resources) to set up.

\section{INFORMAL AND FORMAL INTERACTIONS TO RECRUIT TALENT DEPENDING ON THE FIRM MATURITY LEVEL}

The interactions collected from our literature review seem to be characterised by two dimensions: a degree of formalism and the alignment with a strategic aim, according to the maturity level of a firm or a new venture idea involved in the interaction. In this section, we present a model built on our collection of interactions collected in the literature given above. Our model (Table 1) displays common aims for the interactions sharing the same dimensions, which are in fact intermediary objectives of the interactions towards the recruitment of talent in the Science Park.

The model proposed in this study is based on the motivations of the engaged university to interact with the Science Park or its tenants and vice versa in talent issues. The literature suggests that the university acts as a 'provider of talent, knowledge, and innovation' (Florida, 1999, p. 68), and it feeds the region with a steady flow of talent (Etzkowitz \& Klofsten, 2005). This process occurs first in the attraction of renowned scientists and engineers, who in turn attract talented students who are potential inventors and entrepreneurs as well as future skilled labour for park companies (Florida, 1999), suggesting that the university plays both an entrepreneurial role by taking part in the local economic development and an engaged role by being involved in the social development of its region.

On the one hand, entrepreneurial universities and Science Parks interact both to assist the creation of new knowledge-intensive enterprises (Klofsten \& Lundmark, 2016) as well as to support the business growth of the park's tenant companies (Klofsten \& Jones-Evans, 2013). In this way, the purpose of the interactions and the way in which they occur are directly dependent on the maturity level of the companies involved, as well as the entrepreneurial behaviour of the university; and the recruitment of talent to the park's companies is one of the desired results.

The level of maturity of companies varies within a spectrum that has its beginning in small firms in their initial phase of establishment, traversing to the companies that already have experienced management teams and well-established development programmes (Klofsten \& Jones-Evans, 2013).

University students and researchers, or even corporate employees, are potential entrepreneurs who can create new ventures, leading them through the early stages 
of the enterprise development. In order to adequately support new entrepreneurs, the universities can offer (i) training courses and programs to develop entrepreneurship; (ii) consulting with business advisors; and (iii) incubator facilities and services (Harper \& Georghiou, 2005; Klofsten \& Lundmark, 2016) - making it itself entrepreneurial. Interactions of the entrepreneurial university with well-established companies in the park occur, among other forms, through technology transfers, consultancies of specialised university personnel, or training of company employees or hiring researchers or graduate students by the companies involved (Harper \& Georghiou, 2005).

On the other hand, the existence of formal and informal links between university and industry was first mentioned in 1981 by the OECD, and for example, Löfsten and Lindelöf (2002) used this terminology in their research. However, our literature review has a much narrower focus, as it deals with Science Park-university interactions in order to recruit talent for the Science Park. As we have been reviewing the literature concerning interactions between Science Parks or their tenants and their nearby universities, we have been guided by the proposition of a taxonomy of links that can occur between on park firms and the universities as proposed by Vedovello (1997). In this taxonomy, three categories of links are defined: formal links, informal links and human resources links. ' $[\ldots]$ formal links $[\ldots]$ presuppose the establishment of formal contracts between the partners, with both the commitment and the payment of fees previously established' (Vedovello, 1997, p. 494). Informal links and human resources links do not require formal contracts. What differentiates these two categories is that 'human resources links' deal specifically with informal individual relations whereas 'informal links' concern material and knowledge exchanges. This taxonomy was found relevant and used by other authors, such as Phillimore (1999) for his study on the Western Australian Technology Park, and Bakouros, Mardas and Varsakelis' (2002) study of Greek Science Parks. We also chose to use this categorisation; however, we chose not to keep the 'human resources links' (Vedovello, 1997, p. 494). In our case, the recruitment of talent for the Science Park is the aim of the interactions, so human resources issues should be considered as aims rather than as interactions. Thus, we define:

- Formal interactions as interactions implying a written agreement or contract between the Science Park or its tenants and the engaged university that can but does not necessarily involve a money transaction;

- Informal interactions as all the other interactions that are not determined by the establishment of a formal contract between the Science Park or its tenants and the engaged university.

Defining those two descriptive dimensions of the interactions collected in the literature, as showed in Table 2, enabled us to create our classification of interactions, all aiming at recruiting and developing talent for the Science Park. 
Table 2. Interactions collected in the literature

\begin{tabular}{|c|c|c|c|}
\hline & & \multicolumn{2}{|c|}{ Interactions with Science Park tenants having a: } \\
\hline & & Lower maturity & Higher maturity \\
\hline \multirow{10}{*}{ : } & \multirow{8}{*}{ Formal } & $\begin{array}{l}\text { Organise or participate in education } \\
\text { and training programmes. } \\
\text { (Klofsten \& Jones-Evans, 2013; } \\
\text { Vedovello, 1997) }\end{array}$ & $\begin{array}{l}\text { Recruitment of graduates. } \\
\text { (Hommen et al., 2006; Löfsten \& } \\
\text { Lindelöf, 2002; Vedovello, 1997; } \\
\text { Walcott, 2002) }\end{array}$ \\
\hline & & $\begin{array}{l}\text { Provision of resources to help stu- } \\
\text { dents become self-employed. } \\
\text { (Huffman \& Quigley, 2002) }\end{array}$ & $\begin{array}{c}\text { Internship programmes. } \\
\text { (Hommen et al., 2006; Huffman \& } \\
\text { Quigley, 2002; Walcott, 2002) }\end{array}$ \\
\hline & & $\begin{array}{l}\text { Commercialisation of knowledge. } \\
\text { (Cai \& Liu, 2015) }\end{array}$ & $\begin{array}{l}\text { Scholarships in anticipation of em- } \\
\text { ployment after graduation. (Huffman } \\
\text { \& Quigley, 2002) }\end{array}$ \\
\hline & & $\begin{array}{l}\text { Business plan competitions. } \\
\text { (Huffman \& Quigley, 2002) }\end{array}$ & $\begin{array}{l}\text { Job fairs on the university campus. } \\
\text { (Hommen et al., 2006; Huffman \& } \\
\text { Quigley, 2002) }\end{array}$ \\
\hline & & $\begin{array}{l}\text { Breakfast meetings and seminars ac- } \\
\text { cessible through membership to en- } \\
\text { trepreneur club. } \\
\text { (Klofsten \& Jones-Evans, 2013) }\end{array}$ & $\begin{array}{l}\text { Researchers and students' involve- } \\
\text { ment in projects. } \\
\text { (Vedovello, 1997) }\end{array}$ \\
\hline & & $\begin{array}{c}\text { Use of university’s facilities. } \\
\text { (Walcott, 2002; Westhead \& Storey, } \\
\text { 1995) }\end{array}$ & $\begin{array}{c}\text { Engagement of university academic } \\
\text { staff for consultancy. } \\
\text { (Vedovello, 1997) }\end{array}$ \\
\hline & & $\begin{array}{c}\text { Incubators. } \\
\text { (Huffman \& Quigley, 2002) }\end{array}$ & $\begin{array}{l}\text { Involvement of universities in park } \\
\text { ownership/management. } \\
\text { (Albahari et al., 2013) }\end{array}$ \\
\hline & & $\begin{array}{l}\text { Regional Innovation Systems. } \\
\text { (Coenen, 2007) }\end{array}$ & $\begin{array}{c}\text { Headhunting. } \\
\text { (Zhu \& Tann, 2005) }\end{array}$ \\
\hline & \multirow[t]{2}{*}{ Informal } & $\begin{array}{l}\text { Support for academic entrepreneur- } \\
\text { ship. } \\
\text { (Bienkowska et al., 2016; Díez-Vial } \\
\text { \& Montoro-Sánchez, 2016; } \\
\text { Etzkowitz \& Klofsten, 2005; } \\
\text { Klofsten \& Jones-Evans, 2013; } \\
\text { Klofsten \& Lundmark, 2016; } \\
\text { Martínez-Cañas \& Ruiz-Palomino, } \\
\text { 2010) }\end{array}$ & $\begin{array}{l}\text { Marketing the business school to pre- } \\
\text { viously chosen companies and ob- } \\
\text { taining information regarding hiring } \\
\text { trends. } \\
\text { (Huffman \& Quigley, 2002) }\end{array}$ \\
\hline & & $\begin{array}{l}\text { Human resources flow, mobility re- } \\
\text { sulting in the creation of new firms. } \\
\text { (Dahlstrand, 1997) }\end{array}$ & $\begin{array}{l}\begin{array}{l}\text { Human resources flow, mobility re- } \\
\text { sulting in the flow of knowledge and } \\
\text { skills. }\end{array} \\
\text { (Tan, 2006; Zhu \& Tann, 2005) }\end{array}$ \\
\hline
\end{tabular}




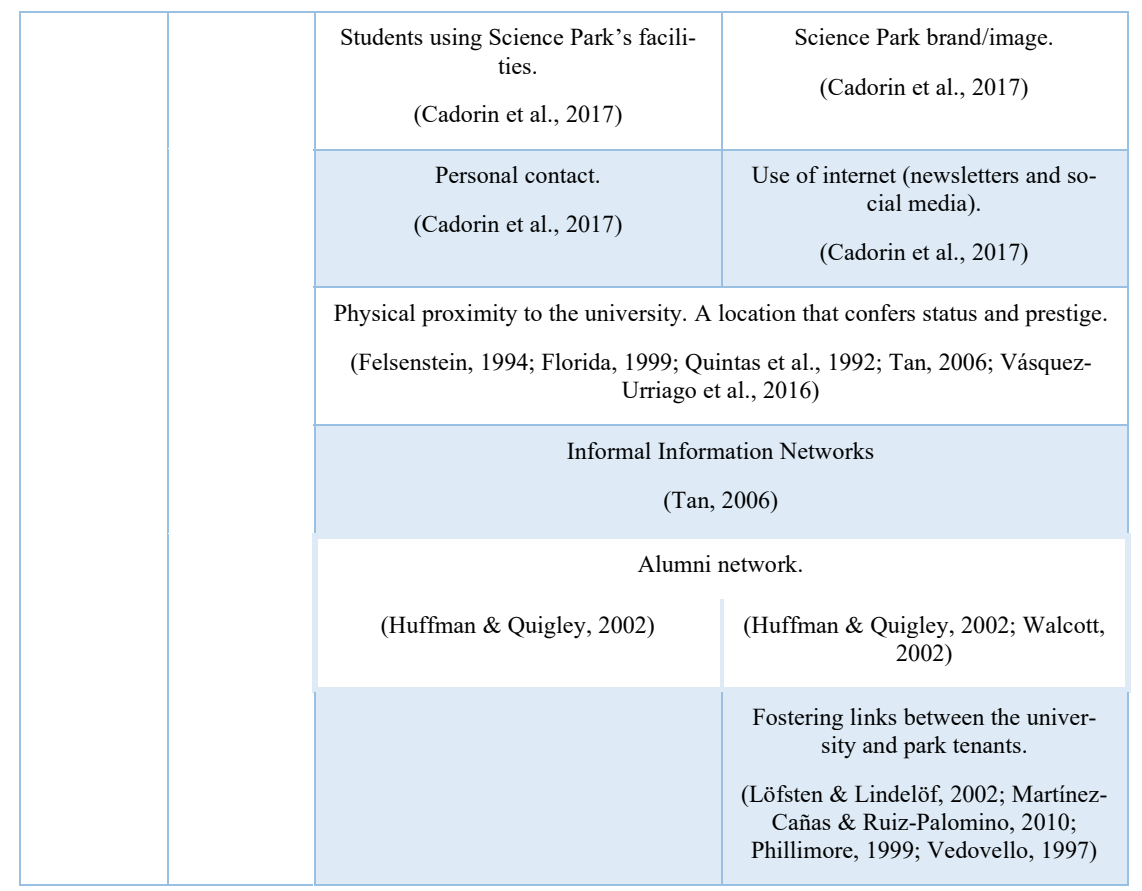

We observe that within each category, the interactions tend towards a common objective that is a step towards their ultimate goal of recruiting talent for the Science Park. Indeed, we observe that:

- for firms or new venture ideas with a lower level of business maturity:

- formal interactions tend to support talent creating their own businesses, resulting in the integration of talent in the Science Park;

o informal interactions tend to create meeting places so that talent can find inspiration and resources to settle their business in the Science Park;

- for firms with a higher level of business maturity:

- formal interactions tend to support businesses in spotting talent in the university, to be able to recruit them after graduation;

o informal interactions tend to create an attractive environment where businesses can spread their need for skills and meet talent.

The categorisation proposed in this paper based on two dimensions, i.e. degree of formality and degree of maturity, is summarised in Table 3 below and further explored through the use of illustrative cases in the next section. 
Table 3. University - Science Park interactions to develop and attract talent.

\begin{tabular}{|c|c|c|c|}
\hline & & \multicolumn{2}{|c|}{ Interactions with Science Park tenants having a: } \\
\hline & & Lower maturity & Higher maturity \\
\hline \multirow{2}{*}{ 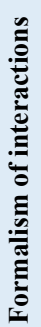 } & Formal & $\begin{array}{l}\text { Support talent in the develop- } \\
\text { ment of new ideas and creation } \\
\text { of new firms. }\end{array}$ & $\begin{array}{l}\text { Support firms in spotting talent } \\
\text { in the university, and create op- } \\
\text { portunities for temporary in- } \\
\text { volvement. }\end{array}$ \\
\hline & Informal & $\begin{array}{l}\text { Create meeting places so that } \\
\text { talent can find inspiration and } \\
\text { resources. }\end{array}$ & $\begin{array}{l}\text { Create an environment where } \\
\text { firms can express their needs for } \\
\text { skills. }\end{array}$ \\
\hline
\end{tabular}

\section{ILLUSTRATIVE CASES OF INTERACTIONS}

In the following section, we present six cases that describe university - Science Park interactions related to talent recruitment. The cases are coherent with our model (Table 4):

Table 4. Illustrative cases from Science Park Mjärdevi

\begin{tabular}{|c|c|c|c|}
\hline & & \multicolumn{2}{|c|}{ Interactions with Science Park tenants having a: } \\
\hline & & Lower maturity & Higher maturity \\
\hline \multirow{4}{*}{ 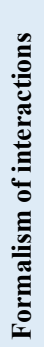 } & \multirow{3}{*}{ Formal } & \multicolumn{2}{|c|}{ Demola } \\
\hline & & LiU Game Awards & LARM \\
\hline & & LiU Innovation & Sommarmatchen \\
\hline & Informal & LEAD incubator & Östgötamorgon \\
\hline
\end{tabular}

\section{LARM}

SPM and student organisations of LiU interact informally to promote recruitment fairs together annually, creating opportunities for companies, regardless of their maturity level, and students to get to know each other. In such interactions, LiU 
has a slight participation or even none. This practice is justified in the words of the SPM Community and Employer Branding Manager:

'[...] for matters regarding talent attraction, I have more interactions with student unions than with LiU as an organisation, because this is a more direct and faster collaboration'.

SPM invites companies, but the contract and payment of the fee are carried out directly with the student union Lintek. Approximately 200 students and 35 companies participated in the 2017 edition.

\section{LiU Innovation}

LIU Innovation is owned by Linköping University (LiU) with the mission to support academic entrepreneurship. Its primary aim is interacting informally with students and researchers to mature their business idea and prepare them with all necessary skills. In the end, the team should be self-sufficient and able to properly conduct their venture to grow into a valuable business in the next stage, that is for some ventures joining the incubator, LEAD. Although LiU owns LiU Innovation and is one owner of LEAD, they are housed in Science Park Mjärdevi facilities, immersed in its business environment and somewhat out of the academic context, representing a smooth integration of the academic and business environment and vice versa.

\section{Sommarmatchen}

Sommarmatchen is a 6-week programme promoted by LiU Innovation, where a group of university students have the opportunity to formally participate and get involved in projects of prospective or newly formed research-based companies of LiU researchers. Temporary hiring during summer holidays allows companies to test the students, who are required to take academic ideas to a different perspective, such as a market analysis.

The links generated by the programme are the basis for the future recruitment of students, allowing them to stay in the region after graduating. This opportunity generation is one of the leading concerns of LiU, according to an innovation adviser at the LiU Innovation office, who states:

'[...] make students stay and start their careers in this region is the challenge of the university, Mjärdevi and Region Östergötland'.

\section{LiU Game Awards}

Linköping University (LiU) annually develops a competition among entrepreneurial students called 'LiU Game Awards'. Science Park Mjärdevi formally participates as an event sponsor. In the competition, students present the games that they have developed, which are evaluated by experts from the gaming industry, and the best games are awarded. These events aim to support students with new ideas and business in their early stages. 


\section{Demola}

Placing students and companies in contact is a means of building the students' entrepreneurial skills and facilitating recruitment as they both have the opportunity to recognise the qualities of the other. Considering this, Linköping University (LiU) offers an entrepreneurship course for interdisciplinary development in cooperation with the international development platform Demola. In this course, students can broaden their networks and also develop their professional skills. The projects are created based on real problems of the companies and students work in teams to offer a solution. The course promotes the integration of companies with students, who are able to demonstrate their qualities, which links to future recruitment. In addition, by working with other students and developing new solutions, there is also the creation of links between students, who may in the future develop a new venture together. Both situations contribute to the recruitment of young university talent.

\section{Östgötamorgon}

The purpose of recruiting talent is not limited to current students but extends to Linköping University (LiU) alumni network. Former students are also desired. In order to attract former students back to the region, the County of Östergötland organises an event called 'Östgötamorgon' in collaboration with LiU, which is in charge of sending invitations to its alumni, Science Park Mjärdevi and twelve municipalities in the region of Eastern Sweden. The event consists of meeting around three times each semester in Stockholm for networking and attending lectures during breakfast. The goal is to strengthen ties with former university students and bring them back to the region as they potentially have extensive business experience and can add value to both small and large park companies.

\section{CONCLUSIONS AND IMPLICATIONS}

The reviewed literature as well as the illustrative cases suggest that universities have been playing their role 'in economic and social development' (Etzkowitz, 2003, p. 110), assuming a mission 'in developing pedagogies and practices that stimulate entrepreneurial attributes and values, provide real insights into the entrepreneurial life-world' (Gibb \& Hannon, 2006, p. 90). By acting entrepreneurially, the university prepares and supports its students and researchers, as well as the workers of the Science Park, in all aspects involving entrepreneurship. This seems facilitated by the existence of a structure and diverse services provided in the associated Science Park - whether by the Science Park office itself or by the university. This engagement of universities in their social and economic environments, however, does not only benefit the emergence of new businesses, but also in-park consolidated companies, for instance. They might also gain the opportunity to in- 
teract with university students during their studies or even after graduation, allowing them to select the best professionals for them, in terms of qualifications and alignment with the company profile.

One of our main aims was to search the literature for theory regarding the interactions occurring between engaged universities and Science Parks to recruit talent for on-park firms. While looking for an answer to our first research question, we noticed that some interactions are mentioned, but in most cases, university - Science Park relations and talent recruitment are treated separately in academic literature. Our literature review has highlighted the fact that these interactions can be characterised by two dimensions in particular: the degree of formality (Vedovello, 1997); and the degree of maturity of the involved firm (Klofsten \& Jones-Evans, 2013). Our literature review has also raised questions regarding the stakeholders involved in the interactions: even though we have been focussing on interactions between the engaged university and the Science Park, both organisations gather multiple stakeholders: for instance, interactions can occur between the Science Park management office, or tenant firms, and between the university administration, or organisations belonging to the university, or even student organisations.

Furthermore, we have studied more in depth how the formal and informal interactions contribute to the recruitment of talent, for firms with different levels of business maturity. Our classification of interactions lead us to distinguish four main types, thus answering our second research question: (i) creating meeting places, where firms can diffuse their need for specific skills and (ii) meeting talent (Huffman \& Quigley, 2002; Tan, 2006), and (iii) where talent can find an attractive environment to start a new business (Cadorin et al., 2017; Díez-Vial \& Montoro-Sánchez, 2016); (iv) spotting talent (Hommen et al., 2006; Walcott, 2002); and (iv) supporting talent in their creation of new companies (Huffman \& Quigley, 2002; Westhead \& Storey, 1995). Beyond classifying the interactions collected from the literature, this theoretical model shows intermediary objectives that are used together by Science Parks and their nearby engaged universities to facilitate talent recruitment.

Observing the interactions occurring between Linköping University and Science Park Mjärdevi for talent recruitment enabled us to verify that these interactions illustrate what we have found in the literature. For example, firms with a higher level of maturity tend to create formal links with the university in order to renew their staff by recruiting graduates. Recruitment fairs and participation of university students in firm's projects seem to be efficient recruitment tools. On the other hand, new ventures or firms with a lower level of maturity take advantage of the formal links with the university to get a qualified support to develop their business. In this case, the university needs to be entrepreneurial and engaged in developing the entrepreneurship skills of its students by providing training programmes or helping them to develop their ideas by offering consulting services at innovation offices and incubators. The informal links occur mainly considering the geographical proximity of firms and universities as well as their participation in 
events. Young and senior talents can be reached in such events and recruited to companies either with high or low maturity levels.

A number of policy implications arise from this study for engaged universities, Science Parks and their tenant firms. Firstly, university managers might stimulate the entrepreneurial spirit of students and researchers, giving them the opportunity to network, develop their skills, and mature their ideas. Entrepreneurship courses that integrate students and researchers in firm projects, seminars and network events are examples of activities that can contribute to the qualification of the young entrepreneurs so that they are prepared to enter the incubator and later in the Science Park, retaining talent in the region.

Secondly, Science Park managers might be alert to the needs of their tenants and create opportunities for companies and talent to meet and get to know each other. The matching of interests will occur naturally when the environment is open to networking and interactions. Providing such environment should be one of the main objectives of the managers in order to recruit university talent.

Finally, tenant firms need to understand that in order to recruit university talent, they must increase their participation in academic activities, seeking to interact with students and researchers, so that they have the opportunity to get to know companies and their projects better. The participation of the company in academic courses besides contributing to the entrepreneurial training of the students also creates interpersonal and professional bonds that will influence a future recruitment cycle. In order to influence students positively when they are seeking employment, company managers should plan activities to advertise the brand and the company's areas of expertise, in addition to its needs for talent with certain skills. In addition, small actions, such as integrating students and researchers into their networks, creating links and encouraging the discovery of common interests among academics and entrepreneurs, can also contribute to attracting academic talent.

Future research could explore to what extent tenant firms can influence the content of the teaching offer of the engaged university. It could also investigate to what extent the university influences the choices of its nearby firms to orientate their activities towards an area covered by the university, both in terms of research and education. Such studies could develop policy implications for universities to closer adapt their curriculum to the needs of the society, benefiting themselves, as well as the workforce, businesses, and also the economy as such.

\section{ACKNOWLEDGMENTS}

The authors would like to thank the interviewees for their time, interest and participation in this study. We are also grateful to the HELIX Competence Centre, CNPq 
(National Council for Scientific and Technological Development, Brazil), and Marie Skłodowska-Curie Actions (through the RUNIN project) for providing resources necessary to conduct this study.

\section{REFERENCES}

Albahari, A., Catalano, G., \& Landoni, P. (2013). Evaluation of national science park systems: a theoretical framework and its application to the Italian and Spanish systems. Technology Analysis \& Strategic Management, 25(5), 599-614.

Audretsch, D. B. (2014). From the entrepreneurial university to the university for the entrepreneurial society. Journal of Technology Transfer, 39(3), 313-321.

Bakouros, Y. L., Mardas, D. C., \& Varsakelis, N. C. (2002). Science park, a high tech fantasy?: An analysis of the science parks of Greece. Technovation, 22(2), 123-128.

Bienkowska, D., Klofsten, M., \& Rasmussen, E. (2016). PhD Students in the Entrepreneurial University - Perceived Support for Academic Entrepreneurship. European Journal of Education, 51(1), 56-72.

Boschma, R. A. (2005). Proximity and innovation: A critical assessment. Regional Studies, 39(1), 6174.

Breznitz, S. M., \& Feldman, M. P. (2012). The engaged university. Journal of Technology Transfer, 37(2), 139-157.

Cadorin, E., Johansson, S. G., \& Klofsten, M. (2017). Future developments for science parks: Attracting and developing talent. Industry and Higher Education, 31(3), 156-167.

Cai, Y., \& Liu, C. (2015). The roles of universities in fostering knowledge-intensive clusters in Chinese regional innovation systems. Science and Public Policy, 42(1), 15-29.

Charles, D. (2006). Universities as key knowledge infrastructures in regional innovation systems. Innovation: The European Journal of Social Science Research, 19(1), 117-130.

Clarysse, B., Wright, M., Lockett, A., Van de Velde, E., \& Vohora, A. (2005). Spinning out new ventures: A typology of incubation strategies from European research institutions. Journal of Business Venturing, 20(2), 183-216.

Clauss, T., \& Kesting, T. (2017). How businesses should govern knowledge-intensive collaborations with universities: An empirical investigation of university professors. Industrial Marketing Management, 62, 185-198.

Coenen, L. (2007). The role of universities in the regional innovation systems of the North East of England and Scania, Sweden: Providing missing links? Environment and Planning C: Government and Policy, 25(6), 803-821.

Colombo, M. G., \& Delmastro, M. (2002). How effective are technology incubators? Evidence from Italy. Research Policy, 31(7), 1103-1122.

Dahlstrand, A. L. (1997). Growth and inventiveness in technology-based spin-off firms. Research Policy, 26(3), 331-344.

Díez-Vial, I., \& Montoro-Sánchez, Á. (2016). How knowledge links with universities may foster innovation: The case of a science park. Technovation, 50/51, 41-52.

Etzkowitz, H. (2003). Research groups as 'quasi-firms': The invention of the entrepreneurial university. Research Policy, 32(1), 109-121.

Etzkowitz, H., \& Klofsten, M. (2005). The innovating region: toward a theory of knowledge-based regional development. $R \& D$ Management, 35(3), 243-255.

Felsenstein, D. (1994). University-Related Science Parks - 'seedbeds' or 'enclaves' of innovation. Technovation, 14(2), 93-110.

Florida, R. (1999). The Role of the University: Leveraging Talent, Not Technology. Issues in Science and Technology, 15(4), 67-73.

Gibb, A., \& Hannon, P. (2006). Towards the Entrepreneurial University. International Journal of Entrepreneurship Education, 4(1), 73-110.

Gibb, A., Hofer, A.-R., \& Klofsten, M. (2013). The entrepreneurial higher education institution: $a$ review of the concept and its relevance today. 
Harper, J. C., \& Georghiou, L. (2005). Foresight in innovation policy: Shared visions for a science park and business-university links in a city region. Technology Analysis \& Strategic Management, 17(2), 147-160

Hommen, L., Doloreux, D., \& Larsson, E. (2006). Emergence and growth of Mjärdevi Science Park in Linköping, Sweden. European Planning Studies, 14(10), 1331-1361.

Huffman, D., \& Quigley, J. M. (2002). The role of the university in attracting high tech entrepreneurship: A Silicon Valley tale. The Annals of Regional Science, 36(3), 403-419.

IASP. (2017). International Association of Science Parks and Areas of Innovation. Retrieved from http://www.iasp.ws/Our-industry/Definitions

Kesting, T., Kliewe, T., \& Baaken, T. (2014). Impact in university-business cooperation - theoretical perspectives and future directions. Int. J. Technology Transfer and Commercialisation, 13(12).

Klofsten, M., \& Jones-Evans, D. (1996). Stimulation of technology-based small firms, a case study of university-industry cooperation. Technovation, 16(4), 187-193.

Klofsten, M., \& Jones-Evans, D. (2013). Open learning within growing businesses. European Journal of Training and Development, 37(3), 298-312.

Klofsten, M., \& Lundmark, E. (2016). Supporting new spin-off ventures-experiences from a university start-up program. In Academic Spin-Offs and Technology Transfer in Europe: Best Practices and Breakthrough Models (pp. 93-107).

Link, A. N., \& Scott, J. T. (2006). U.S. university research parks. Journal of Productivity Analysis, 25(1), 43-55.

Löfsten, H., \& Lindelöf, P. (2002). Science Parks and the growth of new technology-based firmsacademic-industry links, innovation and markets. Research Policy, 31(6), 859-876.

Martínez-Cañas, R., \& Ruiz-Palomino, P. (2010). Social Capital Generation Inside Science Parks: An Analysis Of Business-University Relationships. International Journal of Management \& Information Systems, 14(4), 45-50.

Mellander, C., \& Florida, R. (2011). Creativity, talent, and regional wages in Sweden. The Annals of Regional Science, 46(3), 637-660.

Minguillo, D., Tijssen, R., \& Thelwall, M. (2015). Do science parks promote research and technology? A scientometric analysis of the UK. Scientometrics, 102(1), 701-725.

National Research Council. (2009). Understanding Research, Science and Technology Parks: Global Best Practices: Report of a Symposium. (C. W. Wessner, Ed.) (Vol. 1). National Academies Press.

Pavlin, S., Kesting, T., \& Baaken, T. (2016). An Integrative View on Higher Education and UniversityBusiness Cooperation in the Light of Academic Entrepreneurship. European Journal of Education, 51(1), 3-9.

Perkmann, M., Tartari, V., McKelvey, M., Autio, E., Broström, A., D’Este, P., ... Sobrero, M. (2013). Academic engagement and commercialisation: A review of the literature on university-industry relations. Research Policy, 42(2), 423-442.

Phan, P. H., Siegel, D. S., \& Wright, M. (2005). Science parks and incubators: observations, synthesis and future research. Journal of Business Venturing, 20(2), 165-182.

Phillimore, J. (1999). Beyond the linear view of innovation in science park evaluation. An analysis of Western Australian Technology Park. Technovation, 19(11), 673-680.

Quintas, P., Wield, D., \& Massey, D. (1992). Academic-industry links and innovation: questioning the science park model. Technovation, 12(3), 161-175.

Radosevic, S., \& Myrzakhmet, M. (2009). Between vision and reality: Promoting innovation through technoparks in an emerging economy. Technovation, 29(10), 645-656.

Rothaermel, F. T., Agung, S. D., \& Jiang, L. (2007). University entrepreneurship: a taxonomy of the literature. Industrial and Corporate Change, 16(4), 691-791.

Schiavone, F., Meles, A., Verdoliva, V., \& Del Giudice, M. (2014). Does location in a science park really matter for firms' intellectual capital performance? Journal of Intellectual Capital, 15(4), 497-515.

Svensson, P., Klofsten, M., \& Etzkowitz, H. (2012). An entrepreneurial university strategy for renewing a declining industrial city: The Norrköping way. European Planning Studies, 20(4), $505-525$.

Tan, J. (2006). Growth of industry clusters and innovation: Lessons from Beijing Zhongguancun Science Park. Journal of Business Venturing, 21(6), 827-850.

UKSPA. (2017). United Kingdom Science Park Association. Retrieved from 
http://www.ukspa.org.uk/our-association/about-us

Uyarra, E. (2010). Conceptualizing the Regional Roles of Universities, Implications and Contradictions. European Planning Studies, 18(8), 1227-1246.

Van Dierdonck, R., Debackere, K., \& Engelen, B. (1990). University-industry relationships: How does the Belgian academic community feel about it? Research Policy, 19(6), 551-566.

Vásquez-Urriago, Á. R., Barge-Gil, A., \& Rico, A. M. (2016). Science and Technology Parks and cooperation for innovation: Empirical evidence from Spain. Research Policy, 45(1), 137-147.

Vedovello, C. (1997). Science parks and university-industry interaction: Geographical proximity between the agents as a driving force. Technovation, 17(9), 491-531.

Walcott, S. M. (2002). Chinese Industrial and Science Parks: Bridging the Gap. The Professional Geographer, 54(3), 349-364.

Westhead, P. (1997). R\&D 'inputs' and 'outputs' of technology-based firms located on and off science parks. $R \& D$ Management, $27(1), 45-62$.

Westhead, P., \& Storey, D. J. (1995). Links between higher education institutions and high technology firms. Omega, 23(4), 345-360.

Youtie, J., \& Shapira, P. (2008). Building an innovation hub: A case study of the transformation of university roles in regional technological and economic development. Research Policy, 37(8), 1188-1204.

Zhu, D., \& Tann, J. (2005). A regional innovation system in a small-sized region: A clustering model in Zhongguancun Science Park. Technology Analysis \& Strategic Management, 17(3), 375390. 